\title{
Regional Marketing as a Factor of Development of Russian Regions Under the Conditions of Market Economy
}

\author{
Yulia I. Dubova
}

Ph.D., Associate Professor of the Department of the Global Economy and Economic Theory of Volgograd State Technical University, Volgograd, Russia, 400005, 1 Prazhskaya St., Apt. 18, Email: dubova_u_i@mail.ru

Irina N. Sherer

Ph.D. in Social Science, Associate Professor of the Chair of HCM Volgograd State Socio-Pedagogical University, Volgograd, Russia

Doi:10.5901/mjss.2016.v7n1p223

\section{Abstract}

\begin{abstract}
The author substantiates the necessity for using regional marketing for development of Russian regions under the conditions of market economy and provides tools of marketing mix for regional marketing. The author determines the sense of territorial marketing, distinguishes and views the elements of marketing mix of regional marketing. As a result of the research, the author comes to the conclusion that within regional marketing, a product is total resource potential of the region, i.e., advantages and possibilities of the region, with activities of regional authorities aimed at satisfaction of social needs of region's population through organization and provision to population of the most important social services that are called collective goods. Lack of quantitative landmarks in the form of income is a problem for marketing of territories. An inseparable part of activities of regional authorities within regional marketing program of development of the territory is active advertising of this region as territory fit for private life of individual and organization of business objects. While functioning as a subject in the market, the region provides the consumers with services for satisfaction of individual and collective needs of various social groups of the region.
\end{abstract}

Keywords: regional marketing, marketing mix, development of Russia's regions, market economy.

\section{Introduction}

Nowadays, even and dynamic development of some or other territories of the country is an important condition of building a modern competitive economy. Each region has to build a positive image, increase the level of business activities, labor initiatives of their citizens, level of life, and activate the investment flows. Traditional programs of regional development, inherited from the Soviet times, ceased to effectively fulfill their functions. At present, there is a need for a new view at regional planning and development, orientation at consumer, ability to form and transform the market in view of current and potential needs, balance the spheres of development and think from marketing positions, learn to "sell", even expensively, the name of the region. Regional marketing will help the territory's managers to develop such a view.

\section{Materials and Research Methods}

Theoretical basis of the research includes the works of modern authors in the sphere of regional marketing: (Manek Kirpalani, 2012), (Bagautdinova et al., 2012), (Du Rand et al., 2013), (Youcheng et al., 2013), (Felzensztein et al., 2014).

As tools of marketing of territories, this research uses marketing mix, a complex of marketing which was developed by theorist of marketing, Professor N. Borden in 1964. One of the variants of this complex is 4P model, which, despite its limitedness, could be used for transitional stage of formation of market institutes and relations during planning of marketing campaigns. In the most used form, marketing mix consists of four sub-mixes of marketing: commodity mix, distributive mix, contract mix, and communicative mix. Each of them has a separate complex of measures, the conduct of which facilitates the formation of appropriate policy in the sphere of region's marketing. 


\section{Research Results and their Discussion}

Marketing activities of the region should be viewed as to elements of marketing mix. Commodity policy. The result of activities of the sector of territory marketing is services - though, they often stay "invisible" for ordinary population of the region, despite the fact that they use it in everyday life and realize their value after the purchase. The service in regional marketing is a coordinated process of cooperation of two or more market subjects, when one side influences the others for the purpose of formation, increase, or reproduction of possibilities of the latter in purchase of fundamental goods (Bagautdinova et al., 2012).

There is a group of goods and services which cannot be provided by the market, as they are needed by many people at the same time; these spheres cannot be regulated only through offer and demand: public and private safety; political legal stability, roads, planning and infrastructure, water supply, refuse collection, development of law, regional authorities' support for business development in the region, etc.

Social foundations are caused by sense, functions, and specifics of regional marketing. Activities of regional authorities are aimed at satisfaction of social needs of population, and services are basic commodity in this case. Thus, regional authorities - in the process of fulfilling their certain functions - provide the population of the region with the most important public services which were transferred by the state to the local level. The public services are services which have high social significance for the main part of population of certain territory; they are provided by municipal (or state) services and financed (partially or fully) by means of corresponding budget (local, regional, federal). This means that production and provision of public services, which belong to the category of municipal collective goods, including social, political, and economic spheres, are the element of municipal product (Correia, 2012).

Consequently, it is possible to present the following definition of regional commodity. On the one hand, regional marketing understands commodity as total resource potential of the region, i.e., advantages and possibilities of the region, and, on the other hand, activities of regional authorities are aimed at satisfaction of social needs of region's population through organization and provision for population of the most important public services, called collective goods (Youcheng et al., 2012):

1) social sphere - healthcare, education, ecology, employment, public and private safety, etc.;

2) political sphere - organization of elections, development of particular programs and projects of activities of authorities, coordination of activities of various political entities, etc.;

3) economic sphere - services for organization and perfection of the system of management of development of regional economy, development of economic subjects of the region: land, housing, resorts, etc.

Regional authorities' use of marketing will stipulate the active formation of conditions for diversification of municipal services.

Contract policy. Lack of quantitative landmarks in the form of income is a problem for territories' marketing. The fully developed system of distribution of municipal products and services and the current prices are the most important aspects of the complex program of territories' marketing.

Communicative policy. Under the conditions of competition for investments, special importance belongs to resurrection and modernization of their business and trade centers, formation of image, and good advertising of the region as a place for life, business, and tourists. Formation of reputation of the region is one of the main goals of regional marketing, which should include the system of informational servicing of clients, including possible investors, and advertising of attractive features of the region for various social layers of population, including businessmen, tourists, etc. "Private sale" of regional commodity (total resource potential of the region) is based on the direct communication with organization's representatives and scientists for the purpose of providing information on the region's advantages, formation of long-term contacts, provision of information and services, collection of offers for modernization of regional commodity, and conduct of marketing events (Popkova \& Tinyakova, 2013b).

Advertising will be effective only when it objectively uses the arguments of the current activities and arguments of future perspectives of region's development, emphasizes its positive sides, and is aimed personally at specific consumers. The arguments of current activities of the region include: provision of individual security of the region's population, state and conditions of exploitation of housing and hotel facilities, indicators of development of road and transport infrastructure, water supply, gas supply, heat supply, and other communal infrastructure, parks, recreational and entertainment areas, quality of healthcare, etc. The arguments of future perspectives of region's development include: creation of new productions, municipal infrastructure, average employment level (especially, among youth) and wellbeing, dynamics of investment flows, etc. (Felzensztein et al., 2014).

An inseparable part of activities of regional authorities within regional marketing program of development of the territory is active advertising of this region as a place good for private life of individual and organization of business 
object. For this purpose, a lot of materials on the region are published in mass-media and Internet sources, which are interesting for various consumers. As a rule, these materials include: complex guides that reflect all key sides of territory's life, leaflets and prospects oriented at potential investors, information for tourists: maps with infrastructure objects and culture sights of the region, guides on structure and rights of local authorities, prospects of specific municipal and federal programs, supported by local authorities (especially, of social focus), business guides, etc. (Popkova et al., 2013)

However, working marketing of territory goes beyond the limits of advertising of municipal authorities as reliable contractors in business. It stipulates the contacts of regional institutes, associations, and enterprises which participate in daily socio-economic growth of the region. Communication policy also supposes formation of the field of public information, single regional system of telecommunications, statistical informational data bases, advertising campaigns, etc. Except for development of advertising for the purpose of implementation of the complex of territories' marketing, there should be organized a service for study of public opinion and propaganda work with local population (Popkova \& Tinyakova, 2013a).

It should be noted that at present, the marketing strategy of development of territory includes the concept of integrated marketing communications which is based in allocation of optimal communication structure of complexes mix according to strategic evaluation of each means and maximization of total influence of all means of promotion. Concept of integrated marketing communications is oriented at the increase of effectiveness of each ruble of spending for promotion of regional commodities and services.

This concept is mainly effective with regard to advertising which becomes more factographic and targeted. Development of regional telecommunications also positively influences the selectability of communications. Emergence of new local TV channels simplifies the access for TV to various subjects that are interested in development of the territory. Local TV adapts easier to specific peculiarities of these specific regional markets (Manek Kirpalani, 2012).

Distributive policy of the region. Very often, distributive policy is conducted for the purpose of timely delivery of commodity from place of production to the recipient. It is performed due to the following measures: analysis and substantiation of sales channels, trade policy, marketing logistics, policy of sales means, policy of placement of production powers, policy of placement of consumers and markets, policy of supplies, storage policy as to final products, etc.

For development of measures for distribution of the complex of territories marketing, thorough segmentation should be conducted and the most interesting - in view of future profits - targeted segment should be chosen; after that, the specifics of distribution from the positions of two aspects of regional characteristics should be viewed: as subject and object of marketing program of territory development.

The region functions as a subject in the market and provides the consumers with services for satisfaction of individual and collective needs for various social groups of the region. Taking into consideration the main characteristics of the service as commodity (intangibility, inseparability, variability, and impossibility for storage), the specifics of planning of distribution of services among final consumers is determined. The selection of the principle of distribution of services among population is one of the difficult questions: who has to get, what exactly, and how much. Besides, there are general issues for distribution of regional services among the population:

- the basis could be the principle of even distribution with the availability of standard minimum for all social groups, the deviation from which is acceptable only with obvious profit;

- for groups with high income, the emphasis is put on distribution according to received income or paid taxes;

- for groups with low income and specific needs (handicapped, pensioners, large families, etc.), additional resources should be received. During distribution of municipal collective services, the distribution channel can participate in provision of any element of the service (for example, formation of package of orders for repair of consumer electronics for pensioners) or the whole complex of services (McManus \& Connell, 2014).

The following indicators could be used for planning of distribution:

1) indicator of acceptable correspondence between the level of service provision and expenses for supporting this service (very often, enterprises reduce the level of service in order to reduce expenses);

2) indicator of probability of visiting the service establishments depending on certain peculiarities;

3) indicator of the number of visits per day, week, etc., depending on the number of services.

\section{Conclusions}

Region, as an object in the market, opens for external - as to this region - individuals the attractiveness of natural, material \& technical, financial, labor, organization, and other resources for the purpose of development of production, social, ecological, cultural, and innovation \& investment spheres of this territory. The region offers its resource potential, 
possibilities, and competitive advantages, i.e., its attractiveness as an object for stimulation of demand for targeted groups of potential investors - and it requires the corresponding informational services.

Informational services, as a necessary infrastructure of regional communications, are provided according to the offer of attractiveness, as a commodity, and are its inseparable part. All the above is presented in the scheme of formation of the structure of regional marketing. A central element of the system of regional marketing is information of all members on needs and interests for the purpose of creation of favorable image for external subjects and attractive conditions for living of all social groups of the region.

It is possible to state that this variant of the system of marketing of the territory coincides with the standard treatment of marketing concept. At that, the informative base of the structure of territory marketing is peculiar for the following elements:

1) adjusted and reasoned local economic policy, the importance and expedience of which is caused by growing competition between the regions;

2) this policy is oriented at the maximal satisfaction of needs of development of regional economy, social sphere of this territory, and entrepreneurs' interests;

3) the whole complex of the tools of territory marketing is used for the purpose of the increase of quality of life of all social groups of population and each particular citizen of the region.

In order to achieve dynamic, effective, stable, and complex development of the territory, it is necessary to use all tools of regional marketing in the complex and single system, excluding the contradictions of influence between them and using the possible synergetic effect from implementation of several simultaneous measures in adjacent spheres of economic life of the region. Only in this case, the measures for regional development will be held not in a chaotic and selective manner, causing separate bursts of interest of external investors for investing into the region, but in planned and constant manner, providing economic growth not only in business sphere, but in social life of local population.

\section{References}

Bagautdinova, N., Gafurov, I., Kalenskaya, N. \&Novenkova, A. (2012). The regional development strategy based on territorial marketing (The Case of Russia). World Applied Sciences Journal, 18 (SPL.ISSUE. 18), 179-184.

Correia, R.A.F. (2011). Territorial marketing: Interaction between industrial and regional networks. International Review on Public and Nonprofit Marketing, 8 (1), 93-95.

Dion, D. \& Sitz, L. (2013). Regional affiliations: Building a marketing strategy on regional ethnicity (pp. 60-77). Marketing Management: A Cultural Perspective.

Felzensztein, C., Brodt, S.E. \& Gimmon, E. (2014). Do strategic marketing and social capital really matter in regional clustersa Lessons from an emerging economy of Latin America. Journal of Business Research, 67 (4), 498-507.

Manek Kirpalani, V.H. (2012). Regional economic and marketing structure (pp. 18-41). Successfully Doing Business/Marketing in Eastern Europe.

McManus, P. \& Connell, J. (2014). Putting places on the map? Marketing rural and regional Australia. Journal of Destination Marketing and Management, 3 (2), 105-113.

Popkova, E.G. \& Tinyakova V.I. (2013a). New Quality of Economic Growth at the Present Stage of Development of the World Economy. World Applied Sciences Journal, 5, 617-622.

Popkova, E.G. \& Tinyakova, V.I. (2013b). Drivers and Contradictions of Formation of New Quality of Economic Growth. Middle-East Journal of Scientific Research, 11, 1635-1640.

Popkova, E.G., S.S. Morkovina, E.V. Patsyuk, E.A. Panyavina \& Popov, E.V. (2013). Marketing Strategy of Overcoming of Lag in Development of Economic Systems. World Applied Sciences Journal, 5, 591-595.

Youcheng, W., Joe, H., Fevzi, O. \&, Sandra, N. (2013). Collaborative marketing in a regional destination: Evidence from central Florida. International Journal of Tourism Research, 15 (3), 285-297.

Felzensztein, C., Brodt, S.E., Gimmon, E. (2014). Do strategic marketing and social capital really matter in regional clustersa Lessons from an emerging economy of Latin America. Journal of Business Research, 67 (4), 498-507.

Youcheng, W., Joe, H.,Fevzi, O., Sandra, N. (2013). Collaborative marketing in a regional destination: Evidence from central Florida. International Journal of Tourism Research, 15 (3), 285-297.

Du Rand, G.E., Heath, E.,Alberts, N. (2013). The role of local and regional food in destination marketing: A South African situation analysis. Wine, Food, and Tourism Marketing, 97-112.

Bagautdinova, N.,Gafurov, I., Kalenskaya, N., Novenkova, A. (2012). The regional development strategy based on territorial marketing (The Case of Russia). World Applied Sciences Journal, 18 (SPL.ISSUE. 18), 179-184.

Manek Kirpalani, V.H. (2012). Regional economic and marketing structure. Successfully Doing Business/Marketing in Eastern Europe, 18-41. 